\title{
The effect of brand equity dimensions on repurchase intention
}

\author{
Ajeng Aquinia ${ }^{1}$ and Euis Soliha ${ }^{2}$ \\ 1,2 Management Department, Faculty of Economics and Business, Stikubank University, Indonesia
}

\begin{abstract}
This research aims to find out the effect of brand equity dimensions (brand awareness, perceived quality, brand association, and brand loyalty) on repurchase intention. The population in this research were the consumers of Starbucks café in Semarang, Indonesia, by purposive technique sampling with the criteria that consumers have been purchase and consume Starbucks product. The data was collected by questionnaire and analyze by validity test, reliability test, and multiple analysis regression tests. Consistent with our proposed hypotheses, the results indicated that perceived quality and brand loyalty positively affect repurchase intention. However, our study suggested that brand awareness negatively affects repurchase intention while brand association not significantly affects repurchase intention.
\end{abstract}

\section{INTRODUCTION}

Along with the current era of globalization, consumers are dealing with various choices with the same product, with almost the same price and quality. It can be seen that in 2019 the number of coffee shops in Indonesia reached more than 2,950 outlets, and increase almost three times compared to 2016 which was only around 1,000 outlets (swa.co.id, 2019). So, the competition is very tight, especially for companies that sell goods and services of the same type. Companies and industries that compete with each other to provide the best for consumers in meeting each with their needs. Terms and conditions for company management to be more careful in marketing strategies that are more effective, efficient, and able to determine competitive strategies, so they can win the competition needed.

One of the most important things to stay competitive is the determination of brand strategy. Consumers make a brand as one of the preferences over the intention to repurchase a product because the brand is one of the distinguishing indicators between one product and another in the market. Besides, the brand also performs valuable functions for the company. The brand also signifies a certain level of quality so that satisfied buyers will become loyal and can easily choose the product again. Repurchase intention is a customer's willingness to engage for the next repurchase behavior. They are willing to repeat purchases on the same brand because that brand was met with their expectation level (Pitaloka \& Gumanti 2019). Brand plays a very important role, one of which is to bridge the expectations of consumers when the company promises something to consumers. Thus it can be seen that there are emotional bonds created between consumers and companies through the brand.

According to Lee (2017), brand equity has a positive effect on repurchase intention. Companies are required to compete fully in terms of preparing loyal customers. Companies increasingly understand the brand to be an important factor in competition and become a valuable company asset. In the other hand the study of Kalesaran et al. (2019) revealed that brand equity in brand awareness dimension is not significantly influence to repurchase intention and also Lawu (2015), found that perceived quality is not influence to repurchase intention, where consumers are not too concerned with product quality or brand differences certain products with other products.

Kotler and Keller (2013) suggested that brand equity is the added value given to products and services, this value can reflect in the way of thinking, feeling, and acting on the brand, price, market share, and 
profitability of the company. The brand is said to have equity, with the consideration that the customer will first know or only hear it from both the media and colleagues. Brand equity provides value for consumers that can influence confidence in making purchasing decisions.

Nowadays the phenomenon of the coffee shop in Indonesia has changed the lifestyle of our society. The rising of local brands coffee shop also makes a new fresh air to this retail, such as Kopi Janji Jiwa, Kopi Kenangan, Kedai Kopi Kulo, Ngopi Doeloe and etc. Starbucks is one of the brands coffee shops from America that continue the competition that occurred in 2020 . This can be seen in the results of the survey that has been conducted as shown in table 1 . Starbucks brand has remained in the top position for the past 3 years. In 2019 Starbucks experienced a decline but Starbucks was able to maintain its position ranked first outperforming other brands in the competition for the coffee café retail category.

One of the things that might cause differences in the Top Brand Index is the difference in brand strength in the intention to repurchase the product. By realizing the important role of the company and providing input from old customers to new customers, Starbucks continues to strengthen its brand equity to be able to influence consumer repurchase intentions. This is done for example by producing high- quality coffee, a comfortable cafe, and a variety of products. The resulting image of the product is considered to meet consumer satisfaction and make it different from competing brands. Therefore our study attempted to analyze the extent to which the strength of Starbucks brand equity (brand awareness, perceived quality, brand association and brand loyalty) influence customers to repurchase their product.

Table 1.

TBI (Top Brand Index)

\begin{tabular}{lccc}
\hline \multirow{2}{*}{ Brand } & \multicolumn{3}{c}{ TBI (Top Brand Index) } \\
\cline { 2 - 4 } & $\mathbf{2 0 1 8}$ & $\mathbf{2 0 1 9}$ & $\mathbf{2 0 2 0}$ \\
\hline Starbucks & $51.9 \%$ & $43.7 \%$ & $43.9 \%$ \\
\hline $\begin{array}{l}\text { The Coffee } \\
\begin{array}{l}\text { Bean \& Tea } \\
\text { Leaf }\end{array}\end{array}$ & $8.6 \%$ & $9.8 \%$ & $11.7 \%$ \\
\hline $\begin{array}{l}\text { Ngopi } \\
\text { Doeloe }\end{array}$ & $1.7 \%$ & $0.4 \%$ & $8.2 \%$ \\
\hline
\end{tabular}

Note. Adapted from Top Brand Award, 2020.

\section{LITERATURE REVIEW AND HYPOTHESES DEVELOPMENT}

\section{The effect of brand awareness on repurchase intention}

According to Aaker (2008) brand awareness is the ability to recognize or recall that a brand is part of the product, and brand awareness in brand equity depends on the level of consumer awareness of the brand. Consumers tend to buy products with brands that they know because people will feel safe with something they already know. Therefore, it can be concluded that usually, a well-known brand has the possibility that the brand can be relied on, stability in business, and quality that can be accounted for.

Brand awareness is also considered as one of the factors that affecting knowledge level of consumers about the brand (Chinomona \& Mazriri, 2017), moreover brand awareness will directly influence the ability of future consumer to know and digging up the information about the brand from their memory or experience (Lawu, 2015). According to Pather (2015), consumers usually get into purchase decision based on investigate approach and this is where the brand awareness become a fundamental as consumers purchase the brand that they have heard of. Pather (2015) proves that brand awareness has a significant influence on repurchase intentions. Based on the explanation above, we formulated the first hypotheses as follows:

\section{H1: Brand awareness has a positive effect on repurchase intention}

\section{The effect of perceived quality on repurchase intention}

According to Aaker (2008), the perception of quality is the perception of consumers of the overall quality or excellence of a product or service that is the same as the intended purpose. Quality perception is one of the key dimensions of brand equity.

Perceived quality also can affect willingness from consumers to buy and the price that consumers will pay (Pather, 2017). Lin et al. (2015) states that high perceived quality will make a through long-term experience that will related to the brand and consumers will recognize the differences 
and superiority of the brand, so they would to choose it rather than the competing brands. Therefore, a positive perceived quality will drive the purchase decision of a product and can also potentially create loyalty towards the product.

This is because the perception of quality is the perception of consumers who, if predictable if the perception of quality is negative, the product will not be liked and will not survive in the market. However, if the perception of quality is positive then the product will be liked. Based on the explanation above, we proposed the second hypotheses as follows:

H2: Perceived quality has a positive effect on repurchase intention

\section{The effect of brand association on repurchase intention}

Brand association is everything that related to the memory of a brand (Aaker, 2008). The values that underlie a brand are sometimes based on certain associated with that brand, which also has the power to depend on experience in communicating the brand association and on the support of the network with other links. In other words, a brand is a set of associations arranged to form a meaning. Sometimes the fundamental value of a brand is the set of associations that shape it, or in other words, what the brand means to the community.

According to Lawu (2015) brand association also influence the process of consumers to look for information and raising up the reason and create a good feeling atmosphere to make a purchase. This is related to everything that is associated with the memory regarding the brand, such as completeness of the features, good service quality, and the benefit given to consumers.

The brand association becomes the foothold of consumers in making purchasing decisions on the brand. This can generate various product attributes and benefits for consumers that can provide specific reasons for consumers to make the purchase process using the brand. Based on the explanation above, we formulated the third hypotheses as follows:
H3: Brand association has a positive effect on repurchase intention

\section{The effect of brand loyalty on repurchase intention}

Aaker (2008) defines brand loyalty as a measure of consumer relationship to a brand. This measure can give an idea about whether or not a consumer may switch to another brand offered by a competitor, especially if the brand is found to be a change, both regarding price or other attributes.

Kalesaran et al. (2019) explained that brand loyalty will be a reflective of a longterm profitability for the company and the brand. Brand loyalty occurs when quality has been experienced, so the higher quality the more it can affect to the brand loyalty (Shalehah et al., 2019). It shows that consumers who are loyal to a brand tend to be more confident with their choices.

A consumer who is very loyal to a brand will not easily move their purchase to another brand, no matter what happens to that brand. When consumer loyalty to a brand increases, the vulnerability of these consumer groups from threats and attacks from competing product brands can be reduced. Thus, brand loyalty is one of the core indicators of brand equity that is related to sales opportunities, which also means a guarantee of the company's profit in the future. Based on the explanation above, we proposed the fourth hypotheses as follows:

H4: Brand loyalty has a positive effect on repurchase intention

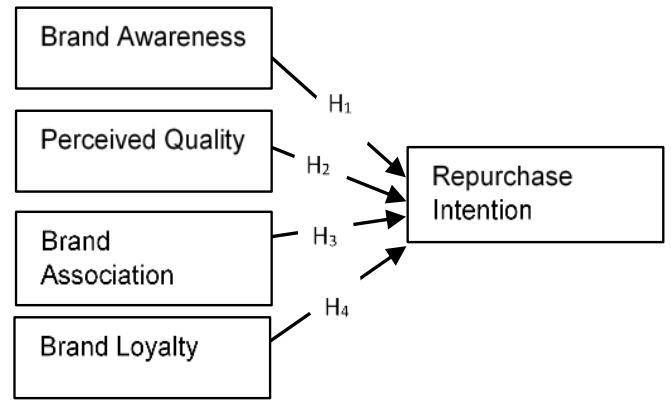

Figure 1.

Conceptual model 
Table 2.

Validity test result

\begin{tabular}{|c|c|c|c|}
\hline Variable & KMO's Value & Indicators & Component Matrix \\
\hline \multirow{3}{*}{ Brand Awareness } & \multirow{3}{*}{0,689} & X1.1 & 0,835 \\
\hline & & $X 1.2$ & 0,821 \\
\hline & & $\mathrm{X} 1.3$ & 0,888 \\
\hline \multirow{3}{*}{ Perceived Quality } & \multirow{3}{*}{0,691} & $\overline{X 2.1}$ & 0,844 \\
\hline & & X2.2 & 0,796 \\
\hline & & $\times 2.3$ & 0,838 \\
\hline \multirow{4}{*}{ Brand Association } & \multirow{4}{*}{0,718} & X3.1 & 0,720 \\
\hline & & X3.2 & 0,762 \\
\hline & & X3.3 & 0,871 \\
\hline & & X3.4 & 0,778 \\
\hline \multirow{4}{*}{ Brand Loyalty } & \multirow{4}{*}{0,820} & $\bar{X} 4.1$ & 0,879 \\
\hline & & $X 4.2$ & 0,866 \\
\hline & & $X 4.3$ & 0,845 \\
\hline & & $X 4.4$ & 0,888 \\
\hline \multirow{4}{*}{ Repurchase Intention } & \multirow{4}{*}{0,835} & $\mathrm{Y} .1$ & 0,865 \\
\hline & & Y.2 & 0,907 \\
\hline & & Y.3 & 0,885 \\
\hline & & Y.4 & 0,923 \\
\hline
\end{tabular}

Table 3.

Reliability test result

\begin{tabular}{lcc}
\hline \multicolumn{1}{c}{ Variable } & Cronbach's $\boldsymbol{\alpha}$ & $\boldsymbol{\alpha}$ standard \\
\hline Brand Awareness & 0,801 & 0,7 \\
Perceived Quality & 0,766 & 0,7 \\
Brand Association & 0,777 & 0,7 \\
Brand Loyalty & 0,882 & 0,7 \\
Repurchase Intention & 0,915 & 0,7 \\
\hline
\end{tabular}

\section{METHODS}

In this research, the population are the people that have been purchased and consumed Starbucks products in Semarang. The number of samples taken was 100 respondents. To measure this research, the respondent filled the questionnaire and also joined the focus group discussion to have an in-depth interview. It takes two months to collect the data, by giving the questionnaire directly to Starbucks consumers. Most of them are women $57 \%$ and the rest are men $43 \%$, with the range of ages between 17-23 years old. Moreover, $49 \%$ of them visits Starbucks for at least one or two times in a month

This research used a validity instrument test, to find out which of indicators that entirely valid. Reliability test, using Cronbach's alpha value to find out reliable variables. Model test by using multiple regression analysis, measures how far the model's ability to explain the effect of independent variables on the dependent variable and significant influence each variable to another (Ghozali, 2011).

\section{RESULTS AND DISCUSSION}

Table 2 shows that the results of the validity test in each study variable the $\mathrm{KMO}$ value is known above 0.50 and therefore the sample coverage is fulfilled. Also, the component matrix values of each indicator that shaped the research variable are more than 0.4 . So, it can be said that the indicator is entirely valid.

Table 3 shows that brand awareness, perceived quality, brand association, brand loyalty, and repurchase intention variables, have a Cronbach alpha value of more than 0,7 . Therefore all variables are declared reliable.

Adjusted $R^{2}$ essentially measures how far the model's ability to explain the effect of independent variables on the dependent variable of the coefficient of determination is between 0 and 1 (Ghozali, 2011). In the table 4 , shows that the coefficient of determination (Adjusted $R^{2}$ ) is 0.731 . This means that 
$73.1 \%$ of variations in repurchase intention can be explained by variations of the four variables namely brand awareness, perceived quality, brand association, brand loyalty while the remaining $26.9 \%$ are explained by other variables outside the model.

In table 4, the overall model test results show an $F$ value of 68.313 with a significance of 0,000 . The significance of the test is smaller than the 0.05 significance level. Thus, the variables of brand awareness, perceived quality, brand association, brand loyalty simultaneously influence to repurchase intention.

\section{The effect of brand awareness on repurchase intention}

Table 4 shows that brand awareness t- value is $-2,089$ with significant value 0,039 less than 0,05 . Thus, the hypothesis which states that brand awareness has a positive effect on repurchase intentions is not supported.

Statistical testing provides evidence that brand awareness is significant, but negatively influences repurchase intentions. This means that there is no influence between brand awareness on repurchase intentions. Based on the focus group discussion method, it was obtained through in-depth interviews with respondents, that there was no longer the effect of brand awareness on repurchase intention Starbucks products, because there were no more differentiators with other coffee shop competitors.

The number of competitors in the world of coffee shops today, makes consumers no longer inclined to repurchase based on brand awareness. According to Aaker (2008), basically brand awareness is the ability to recognize or recall that a brand is part of the product. But in this study, consumers no longer tend to buy based on the brands they know. In this study, inversely proportional to the results of Pather (2017) study which has the result that brand awareness has a positive effect. But this is in line with the result study from Kalesaran et al. (2019) that states brand awareness has no significant influence to repurchase intention.

\section{The effect of perceived quality on repurchase intention}

In table 4 , it is presented that perceived quality t- value is 4,919 with significant value 0,000 less than 0,05 . Therefore, the hypothesis which states that perceived quality has a positive effect on repurchase intentions is supported.

Statistical testing provides evidence that perceived quality has a significant effect on repurchase intentions. This means that there is an influence between the variable perceived quality of repurchase intention. The results of the study provide evidence that the perceived quality will increase the attractiveness of repurchase intentions. This is in line with stated by Aaker (2008), which states that the perceived quality is one of the important dimensions in brand equity, as well as consumers' perceptions of the overall quality or excellence of a product related to what they expect. Besides, according to Lin et al. (2015), high perceived quality means that through long-term experience, customer will recognize the superiority of the brand and choose it rather than another brand. The perception of quality can be explained as a perception of consumers as a whole about the intelligence and quality of products or services, which are compared with other competing products or competitors.

Perceived quality can affect on repurchase intention of a product. An impression of quality could not be set objective side, because this impression is a perception of each subjective individual. So, with a good understanding of quality from

Table 4.

Regression analysis test result

\begin{tabular}{cccccc}
\hline \multicolumn{1}{c}{ Model } & Adj R $^{\mathbf{2}}$ & \multicolumn{2}{c}{ F Test } & \multicolumn{2}{c}{ t Test } \\
\hline \multicolumn{1}{c}{$\mathbf{1}^{\text {st }}$ Equation } & & F & Sig & B & Sig \\
\cline { 3 - 5 } & & 68,313 & 0,000 & & \\
Brand awareness on repurchase intention & 0,731 & & & $-0,289$ & 0,039 \\
Perceived quality on repurchase intention & & & & 4,919 & 0,000 \\
Brand association on repurchase intention & & & 1,241 & 0,218 \\
Brand loyalty on repurchase intention & & & 7,690 & 0,000 \\
\hline
\end{tabular}


consumers, then it can directly increase the power of repurchase intention of a product. Consumers who already know and understand the quality of the product well, there will be appeared to repurchase the Starbucks product.

\section{The effect of brand association on repurchase intention}

Table 4 also shows that brand association tvalue is 1,241 with significant value 0,218 more than 0,05 . Therefore, the hypothesis which states that brand association has a positive effect on repurchase intentions is not supported.

Statistical test proves that brand association is not significant, so it is not influence on repurchase intention. It means there is no effect on brand association towards repurchase intention. According to focus group discussion, there are no differentiator between coffe shop competitors. Most of them is no longer repurchase based on brand association. Aaker (2008) said that brand association is all about things that related to recall about the brand, while Chinomona \& Mazriri (2017) states that brand association shaped on consumers mind about their characteristic or attributes of their products also would help consumers to search and dealing the information of brand. But in this research, the consumers is no longer repurchase based on brand characteristic, or finding out the information about the brand.

\section{The effect of brand loyalty on repurchase intention}

In table 4 it is showed that brand loyalty tvalue is 7,690 with significant value 0,000 less than 0,05 . Therefore, the hypothesis which states that brand loyalty has a positive effect on repurchase intentions is not supported.

Statistical testing provides evidence that the influence of brand loyalty has a significant effect on repurchase intentions. This means that there is an influence between brand loyalty variables on repurchase intentions.

Better brand loyalty will increase repurchase intention. This is following what was stated by Aaker (2008) also Shalehah et al. (2019) and Kalesaran et al. (2019), which states consumers usually will repeat purchase when the quality is high although the price is expensive, and this is shows that consumers are loyal to a certain brand over a period of time. Brand loyalty is a measure that can provide a picture of consumer entanglement with habitual buyers and satisfying products, where these levels consumers are satisfied and repurchase the product because they are usual to do it.

\section{CONCLUSION}

The main findings of this research show that several elements of brand equity has no effect to repurchase intention. For brand awareness and brand associations were not significantly influence to repurchase intention. Consumers no longer repurchase based on their ability to recognize the brand, and also no longer repurchase based on product attributes. There is no differentiator between competitors that sells the same product. On the other hand, perceived quality and brand loyalty have a positive influence to repurchase intention. It means perceived quality became attractiveness on consumers mind repurchasing a product. This shows that perceived quality is an important element related to all of the quality of product and the way they served is fit to what consumers expected. Brand loyalty also played a role in repurchase intention. The company knows exactly how to treat loyal consumers. Consumers were satisfied with a product or service, and that makes them keep loyal to their brand and repurchase the products.

The limitation on this research is only conducted for the respondents who are currently consume Starbucks coffee in Semarang. Therefore, it is uncertainty whether the model on this research can be applies to other regions or area. Moreover, the respondents of this research were mostly came from young respondents, so there was a less opinion from those who were older.

The suggestion for next research is to find another place to take a research, so this model is not only applied for respondent who live in Semarang. An equal distributions of respondents also need to be done so this research can be clearer.

\section{REFERENCES}

Aaker, A. David. 2008. Manajemen Ekuitas Merek. Jakarta: Mitra Utama. 
Chinomona, Richard, and Eugine Tafadzwa Maziriri (2017). The influence of brand awareness, brand association and product quality on brand loyalty and repurchase intention: a case of male consumers for cosmetic brands in South Africa. Journal of Business and Retail Management Research 12.1.

Ghozali, Imam. 2011. Aplikasi Analisis Multivariate Dengan Program IBM SPSS $19 . \quad$ Universitas Diponegoro.Semarang.

Kalesaran, Maesa R., Joyce SLHV Lapian, and Regina T. Saerang (2019). Analyzing The Dimension Of Brand Equity Toward Repurchase Intention Of Kopi Kulo In Manado. Jurnal EMBA: Jurnal Riset Ekonomi, Manajemen, Bisnis dan Akuntansi 7.4. .

Kotler,P. \& Keller,K. L .2013. Marketing Management $14^{\text {th }}$ Edition. Global Edition.Pearson Prentice Hall

Lawu, Bakti Jean Lawas (2015). Pengaruh Elemen Brand Knowledge dan Brand Equity terhadap Repurchase Intention. Jurnal Manajemen Maranatha 14.2

Lee, Joseph (2017). The influence of brand equity on repurchase intention: The moderating effects of justice perceptions and attribution. The proceedings of $2 n d$ Business Doctoral and Emerging Scholars Conference.

Lin, Alex Y-S., Yu-Ting Huang, and Meng-Kai Lin (2015). Customer-based brand equity: The evidence from China. Contemporary Management Research 11.1.

Pather, Pravenshi (2017). Brand equity as a predictor of repurchase intention of male branded cosmetic products in South Africa. Business \& Social Sciences Journal 2.1: 1-23.

Pitaloka, Inggrid Widya, and Tatang Ary Gumanti (2019). The Effects Of Brand Equity On Repurchase Intention: The Role Of Brand Relationship Quality In Muslim Wear Brand SurabayaIndonesia. International Journal of Scientific \& Technology Research 8.1.

Shalehah, Anita, et al. (2019). The Effect of Korean Beauty Product Characteristics on Brand Loyalty and Customer Repurchase Intention in Indonesia. 2019 16th International Conference on Service Systems and Service Management (ICSSSM). IEEE.

Swa.co.id (accessed on 24 Desember 2019) https://swa.co.id/swa/trends/industri- kopi-indonesia-tahun-2020-makinkinclong. 